\title{
Duch udzielony Mesjaszowi w Księdze Izajasza
}

\author{
The Spirit Given to the Messiah in the Book of Isaiah
}

\author{
MARIUSZ SZMAJDZIŃSKI \\ Boczki Chełmońskie \\ mar.szmaj@hoga.pl, ORCID: 0000-0001-5577-8993
}

\begin{abstract}
Streszczenie: Rzeczownik rûạ̣ („duch”, a także „oddech, wiatr”) jest jednym z ważniejszych terminów teologicznych w Starym Testamencie, zwłaszcza gdy występuje w znaczeniu "duch”. Wówczas rûah pozostaje zawsze w mocy Boga i jest zależny od Niego. Jako duch Boży „czuwa” on nad stworzeniem, odnawia wszystko, przywraca do życia, a po śmierci człowieka wraca do Boga, który go dał. W Księdze Izajasza rzeczownik rûa ḥ występuje 51 razy. Bardzo ważną rolę odgrywa w wyroczniach, które zapowiadają i ukazują mesjasza: Iz 11,1-3a, 42,1 i 61,1. Duch jest mu udzielony jako moc Boża do wypełnienia ważnych zadań. Bóg udziela ducha w sposób trwały. Dzięki duchowi tworzy się szczególna relacja pomiędzy Bogiem a mesjaszem, która jest wyrażona takimi tytułami jak „mój sługa” lub „mój wybrany”. Jego misja jest skierowana przede wszystkim do ubogich i chorych. Jej skutkiem będzie zmiana ich sytuacji przez ustanowienie prawa i sprawiedliwości. Działalność mesjasza przekroczy granice Izraela i zostanie skierowana do wszystkich narodów. Dzięki niemu poganie będą oświeceni Bożym światłem i będą uczestniczyli w przymierzu. W takim znaczeniu wyrocznie mesjańskie z Księgi Izajasza występują w Nowym Testamencie (Mt 12,18-20; Łk 4,18-19).
\end{abstract}

Słowa klucze: duch Boży, mesjasz, Księga Izajasza.

\begin{abstract}
The noun rûa ("a spirit", as well as "breath, wind") is one of the most important theological terms in the OT, especially as it occurs in the sense of "spirit". As such, rûa always remains within the power of God and depends on Him. Being God's spirit, it "supervises" over all creatures, renews everything, restores to life, and after a person's death it returns to the God who gave Him. The noun rûa occurs 51 times in the Book of Isaiah and it plays a very important role in the oracles that announce and reveal the messiah: Isaiah 11:1-3a, 42:1, and 61:1. The spirit is given to him as God's power to perform important tasks. God gives His spirit permanently. The spirit creates a special relationship between God and the messiah, which is expressed in titles such as "my servant" or "my chosen one". His mission is aimed primarily at the poor and the sick. Its result is a change in their situation, by the enacting of righteousness and justice. The messiah's activity crosses Israel's borders and will be directed to all nations. In this way the pagans will be enlightened with God's light and will participate in His covenant. It is within this domain of meaning that the messianic oracles from the Book of Isaiah are conveyed into the New Testament (Matthews 12:18-20; Luke 4:18-19).
\end{abstract}

Keywords: spirit of God, messiah, The Book of Isaiah.

„Duch Pański spoczywa na Mnie, ponieważ mnie namaścił i posłał Mnie...” - to początek proroctwa, które Pan Jezus odczytał w nazaretańskiej synagodze (Łk 4,18). Izajaszowe zapowiedzi o głoszeniu ubogim dobrej nowiny oraz udzieleniu darów, streszczających się w określeniu „rok łaski od Pana”, odniósł On do siebie, oznajmiając: „Dziś zostało wypełnione Pismo, które usłyszeliście” (Łk 4,21). Dlatego cała 
perykopa Łk 4,16-30 została nazwana „manifestem nazaretańskim, ponieważ zawiera cały program działania Mesjasza namaszczonego Duchem Świętym”'. Święty Łukasz ukazuje misję Pana Jezusa jako realizację Izajaszowego proroctwa, stwierdzając w ostatniej części, że był On „prorokiem potężnym w czynie i słowie” (Łk 24,19). Należy jednak pamiętać, że prorocka autodeklaracja („Duch Pański spoczywa na mnie”) stanowi konkluzję tekstów, w których jest mowa o udzieleniu ducha Pańskiego pewnej szczególnej (i w nurcie Starego Testamentu jeszcze tajemniczej) postaci, określanej jako mesjasz. Prezentowany artykuł jest próbą ukazania udzielenia tego daru na podstawie Księgi Izajasza.

\section{Duch (rûaḥ) jako forma obecności Boga w Starym Testamencie}

Hebrajski rzeczownik $r \hat{u}^{a} h$ ma szereg znaczeń: wiatr, oddech, tchnienie, duch (jako źródło/siła życia) czy moc, którą posiada tylko Bóg². Oznacza więc to, co jest nieuchwytne i będące w ruchu, w stanie ciągłego przemieszczania się, oraz to, co niewidzialne. Więcej, rzeczywistość określona tym mianem wprawia w ruch lub obdarza życiem, względnie je podtrzymuje. Znamienne jest to, że w tekstach starotestamentowych działanie i przemieszczanie się r $\hat{u}^{a} h$ możliwe jest we wszystkich kierunkach, ale nie jest on ślepy i niekontrolowany, zawsze (jako wiatr, oddech, duch) pozostaje w mocy Boga i jest zależny od Niego. Bóg ma ponadto pełną władzę nad rû́ $a h$ i używa go jako swojego posłańca (Ps 104,3-4). Można nawet zauważyć pewną dynamiczną moc ducha, jaka objawia się w historii zbawienia i w życiu człowieka: od samego początku „czuwa” on nad stworzeniem ( $\operatorname{Rdz} 1,2$ ), odnawia wszystko (Ps 104,30), a nawet przywraca do życia (Ez 36,26-27; 37,9-10). Po śmierci człowieka $r \hat{u}^{a} h$, rozumiany jako duch ożywiający, wraca do Boga, który go mu dał (Koh 12,7).

Pochodzenie i zależność ducha od Boga wyraża w Starym Testamencie syn-

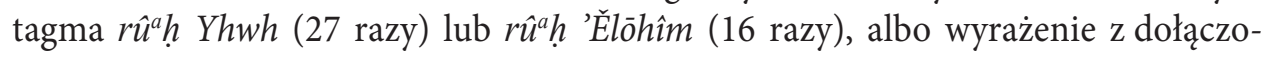
nym sufiksem zaimka dzierżawczego (rûhĥ, rûhăk̄ā, rûhhô [26 razy]) $)^{3}$ Duch Boży jest darem, który zostaje udzielony zarówno jednostce, jak i wspólnocie. W sposób szczególny spoczywał on na osobach, które miały do wypełnienia wyjątkową misję, jak na przykład przewodzący wspólnocie ludu wybranego (Mojżesz [11,17], Jozue [Lb 27,15-21; Pwt 34,9], sędziowie [Sdz 3,10; 6,34; 11,29; 13,25], a zwłaszcza Dawid [1Sm 16,13]) czy prorocy przemawiający do Izraela (Iz 48,16; Ez 2,2; Mi 3,8; Za 7,12)4.

\footnotetext{
Por. Kudasiewicz, „Mesjańska działalność”, 212-213.

Por. BDB, 924-926; HALOT III, 1197-1201.

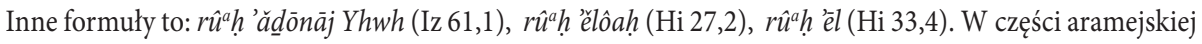
Starego Testamentu występuje wyrażanie rü $\hat{u}^{a}$ 'ělāhî̀n (qaddî̌šn) (Dn 4,5.6.15; 5,11.14).

Por. Alberts - Westermann, „rî $\hat{u}^{a} h$ - spirit”, 1202-1220.
} 
W myśli teologicznej Starego Testamentu duch pełni bardzo ważną rolę. Jest on bowiem jedną z czterech form obecności Boga (podobnie jak Jego oblicze, imię i chwała). W tym kontekście $r \hat{u}^{a} h$ jest mocą, poprzez którą Yhwh odsłania swoją obecność. Można wyróżnić cztery kategorie tej działalności5.

1) Duch Boży to stały dar, który umożliwia życie. Jest ono, zwłaszcza w przypadku człowieka, przejawem działania r $\hat{u}^{a} h \underline{h}$ Yhwh. To oznacza trwałą i dynamiczną więź z Bogiem.

2) Duch Boży to dar, który jakaś osoba otrzymuje w celu podjęcia oczekiwanego działania na korzyść ludu Bożego. Wówczas staje się ona innym człowiekiem, obdarzonym siłą i szczególnymi charyzmatami. Tak właśnie było w przypadku sędziów (Otniel [Sdz 3,10], Gedeon [Sdz 6,34], Jefte [Sdz 11,29], Samson [Sdz 14,1]) oraz królów (Saul [1Sm 11,6], Dawid [1Sm 16,13]). Udzielenie r $\hat{u}^{a} h$ Y Yhwh przybierało także wymiar prorocki (Józef [Rdz 41,38], Mojżesz [Lb 11,24-29], Balaam [Lb 24,2], Saul [1Sm 10,6], Dawid [2Sm 23,2], Eliasz [1 Krl 18,12], Micheasz [1Krl 22,24], Ezechiel [Ez 11,5]).

3) Duch Boży to moc działająca i kształtująca dzieje Izraela, który dzięki niej mógł bez większych trudności pokonać wszelkie przeszkody i kształtować swoje życie w sposób odpowiadający jego powołaniu. Udzielenie tego daru dawało Izraelowi także gwarancję, że Bóg jest obecny ze swoim ludem (Ag 2,5; Za 4,6). „Dobry duch" (hebr. $\left.r \hat{u}^{a} h \underline{t} t \hat{b} \underline{b} \hat{a}\right)$ daje poczucie bezpieczeństwa i prowadzi człowieka lub cały naród do wyznaczonego miejsca (Ps 143,10).

4) Duch Boży to eschatologiczny dar, który daje moc. Został on obiecany przez Boga. Był więc oczekiwany przez lud wybrany, który dzięki niemu mógł poznać Boga, doświadczać Jego obecności i trwania we wzajemnej relacji z Nim. To odróżnia Boga Izraela od pogańskich bożków. One bowiem nie mają w sobie żadnego dynamizmu, czyli ducha zapewniającego moc, który umożliwiałby komunię pomiędzy nimi a ich czcicielami.

Całe to bogactwo, które wypływa z wyrażenia $r \hat{u}^{a} h$ Yhwh, zostało przejęte i dopełnione przez proroków (np. Micheasza [3,8], Ezechiela [11,5; 37,14], Zachariasza [4,6], Joela [3,1-2]). Szczególne znaczenie w tym względzie mają wyrocznie z Księgi Izajasza (11,1-3; 42,1 i 61,1). Znajdują się one w trzech różnych częściach tej księgi, a więc powstały w różnych czasach, środowiskach i uwarunkowaniach historycznych.

\section{Rzeczownik rûa h w Księdze Izajasza}

W Księdze Izajasza rzeczownik $r \hat{u}^{a} h \underline{h}$ występuje 51 razy. Pod względem częstotliwości i stosunku do występującego słownictwa ten termin pojawia się częściej jedynie

$5 \quad$ Por. Witczyk, Pokorny wołał, 306-314. 
w Księdze Ezechiela (52 razy). Izajasz, a właściwie autorzy księgi zatytułowanej tym imieniem, używają tego rzeczownika w różnym znaczeniu, a co z tego wynika, przypisują mu różne działania i funkcje. To szerokie spektrum można podzielić na następujące grupy:

1) $r \hat{u}^{a} h$ jako wiatr: 7,$2 ; 11,15 ; 17,13 ; 26,18 ; 27,8 ; 32,2 ; 40,7$ (r⿲彳⿳⺈⿴囗十 $h$ Yhwh); 41,16.29; 57,13; 59,19 (r. $\hat{u}^{a} h$ Yhwh); 64,5.

2) W odniesieniu do świata przyrody: duch jako przeciwstawienie ciała/mięsa (bāśär): 31,3.

3) W odniesieniu do ludzi: (a) duch jako życie: 19,3 ; 38,16; 57,16; (b) stan wewnętrzny: 26,9; 29,24; 54,6; 57,15; 61,3; 65,14; 66,2; (c) siła człowieka: 11,4; 25,4.

4) W odniesieniu do Boga: (a) rû́h oznaczający samego Boga: 34,16; 40,13; 63,10; (b) tchnienie/oddech jako wyraz Bożego gniewu: 4,4; 30,28; 33,116; (c) duch zesłany od Boga, zmieniający usposobienie lub kondycję człowieka na jego niekorzyść: 19,14; 29,10 (duch mocnego snu = brak proroctwa); 37,7; (d) duch dający życie lub wpływający na działanie człowieka: 30,1; 32,15; 42,5; 44,3; 63,14; (e) duch jako dar Boży udzielony w wymiarze indywidualnym: 11,2-3a; 28,6; 42,1; 48,$16 ; 59,21 ; 61,1 ; 63,11$.

Ten przegląd pokazuje, że w Księdze Izajasza rzeczownik rî̀ $h$ występuje we wszystkich możliwych znaczeniach. Jest to więc wiatr rozumiany jako żywioł, który powoduje zmiany w przyrodzie $(11,15)$ lub wywołuje zniszczenie $(17,13 ; 27,8 ; 32,2)$. W tym znaczeniu $r \hat{u}^{a} h$ występuje także w porównaniach jako synonim nicości $(26,18$; $41,29)$ lub przejaw lęku $(7,2)$. Ciekawy też jest kontrast w 31,3, gdzie temu rzeczownikowi jest przeciwstawiony bāśār (mięso, ciało), analogicznie do zestawienia 'èl ’âdām (Bóg - człowiek). Kolejne znaczenie, w jakim pojawia się rûa $h$ w Księdze Izajasza, to duch obdarzający i/lub podtrzymujący życie w człowieku $(38,16)$ bądź całe narody $(19,3)$. Ponadto w odniesieniu do człowieka może także służyć na oznaczenie jego stanu wewnętrznego $(26,9 ; 61,3)$, błądzenia $(29,24)$ lub siły $(11,4 ; 25,4)$. Jednak najczęściej, bo prawie połowa wystąpień tego rzeczownika, odnosi się do Boga. Dwukrotnie $r \hat{u}^{a} h$ jest użyty wręcz jako synonim $Y h w h(34,16 ; 40,13$ i 63,10). Częściej jednak jest to duch, którego Bóg udziela człowiekowi lub narodowi. W tym przypadku można wyróżnić negatywną i pozytywną stronę takiego obdarowania. Duch Boży może być - w negatywnym działaniu - przyczyną stanu odrętwienia $(29,10)$, przejawem kary $(19,14)$ lub narzędziem wyroku $(4,4 ; 30,28 ; 33,11)$. Natomiast pozytywne działanie $r \hat{u}^{a} h$ to: obdarzenie życiem $(42,5)$, pokojem $(63,14)$, uzdolnienie do wykonania powierzonej misji $(30,1)$ albo zapewnienie błogosławieństwa $(32,15$; 44,3). Do osobnej grupy należy zaliczyć te teksty z Księgi Izajasza, w których jest mowa o udzieleniu ducha w wymiarze indywidualnym. Jest to przykładowo święty duch, którym został napełniony Mojżesz $(63,11)$, albo duch sprawiedliwości $\left(r \hat{u}^{a} h\right.$ mišpāt $)$ udzielony władcy zasiadającemu na tronie $(28,6)$. Również prorocy byli ob-

6 Wyrażenie rûhăkem poprawione na rûhîkamô na podstawie aparatu krytycznego BHS. 
darzeni tym darem, dzięki czemu mogli do końca wypełnić powierzoną im misję $(48,16 ; 59,21)$. W tej grupie są także teksty, które wiążą ducha z osobą wybraną przez Boga, powołaną i posłaną do wykonania powierzonego zadania, a jednocześnie do reprezentowania Go wobec ludzi będących adresatami Bożego orędzia (11,2-3a; 49,1; 61,1). W tradycji biblijnej odczytano te teksty jako zapowiedzi mesjańskie. Obecność i oddziaływanie ducha Bożego na postać obecną w tych tekstach, czyli mesjasza, będą przedmiotem dalszej analizy.

\section{Iz 11,1-3a}

Wyrocznia jest jedną z zapowiedzi mesjańskich zawartych w Iz 1-117 . Odnosi się ona bezpośrednio do dynastii Dawidowej, która została określona jako gēzac. Ten rzeczownik oznacza goły pień drzewa, ucięty i zwalony kloc drewna, a także pień tkwiący swoimi korzeniami w ziemi, a więc mogący jeszcze wydać nowe pędy i gałązki (Hi 14,8; Iz 40,24) $)^{8}$. Z powodu grzechów, zwłaszcza braku wiary (Iz 7,9.10-16), oraz dramatów politycznych królewski ród jest ukazany w Iz 11,1 jako ścięte drzewo. Porównanie jest zgodne z wcześniejszymi wyroczniami Izajasza, w których ukazuje on sytuację całego Królestwa Południowego jako kraju spustoszonego, winnicy ze zburzonym murem, a przez to wystawionego na grabież i podeptanie, pola porośniętego ostami i cierniami oraz narodu żyjącego w nędzy $(5,1-7 ; 6,11-13 ; 7,21-25 ; 10,17-23)$. Jednak wyrocznia Iz 11 budzi nadzieję na całkowitą odmianę - przy użyciu obrazu powalonego pnia prorok pokazuje, że dynastia królewska odrodzi się dzięki „nowej odrośli”, czyli dzięki potomkowi, który wyrośnie i zakwitnie. Owo „wyrośnie” i „zakwitnie" oznacza, że wypełnią się obietnice złożone Dawidowi, dotyczące jego potomka (2Sm 7,10-16). W ten sposób Izajasz podkreśla, że Bóg jest wierny swojemu słowu. Suchy pień wypuści świeżą odrośl (hōtẹr), a korzeń - młody pęd (nēṣer) ${ }^{9}$. Natomiast świeżość i nowość w przypadku nēṣer zapewnia sam Bóg (Iz 60,21; Dn 11,7). Użyte słownictwo wskazuje na królewskość i boskie pochodzenie owej „odrośli”. Ponadto użycie liczby pojedynczej zwraca uwagę na jednostkę, jedną postać. Obraz na nowo wyrastającego pędu wzmacnia dodatkowo metafora w Iz 10,33-34, a więc bezpośrednio przed omawianą wyrocznią. Prorok mówi, że Bóg powycina wysokie i wzniosłe drzewa. Tak została zobrazowana kara, jaka miała spaść na asyryjskiego władcę za jego pychę (Iz 10,13-19).

7 Na temat zapowiedzi mesjańskich w pierwszej części Księgi Izajasza (1-12) zob. Paściak, Izajasz, 23-81; Synowiec, Oto twój król, 71-95; Krawczyk, Nadzieje mesjańskie, 75-98.

8 Por. BDB, 628; HALOT II, 679-680.

9 Rzeczownik ḥọter oznacza także rózgę (Prz 14,3) lub znak władzy (np. laska, berło, por. akad. i ugar. hatțu). 
Ożywienie dynastii Dawidowej, zrodzonej $\mathrm{z}$ „pnia Jessego" ${ }^{10}$, będzie możliwe tylko dzięki duchowi udzielonemu przez Boga ${ }^{11}$. Zapowiedź wyrażona w Iz 11,1-3 odnosi się więc do mesjasza, choć to określenie nie pojawia się tu wprost.

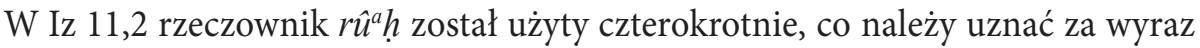
pełni udzielenia tego daru. Liczba cztery ma bowiem symboliczne znaczenie. Tyleż jest żywiołów, stron świata, pór roku, głównych wiatrów, a także głównych epok w dziejach ludzkości (por. Owidiusz, Przemiany, 89-150). Ponadto w Iz 11,2 są trzy pary dookreślania ducha. To połączenie (cztery plus trzy) daje liczbę siedem, która w symbolice biblijnej oznacza pełnię i doskonałość. Użycie tych liczb wskazuje na potęgę działania $r \hat{u}^{a} h \underline{Y}$ Yhwh i jego boskie pochodzenie.

Wszystkie zastosowane środki stylistyczne i gramatyczne wyrażają doniosłość i niezwykłość wydarzenia, czyli wyjątkowe i pełne udzielenie ducha Bożego mesjaszowi ${ }^{12}$.

Na „odrośli Dawidowej” duch Boży spocznie w sposób stały, a nie przejściowy. Nie będzie to więc doraźna pomoc czy czasowe uzdolnienie udzielone w obliczu pewnego kryzysu, jak było w przypadku Gedeona (Sdz 6,34) czy Samsona (Sdz 13,25). Świadczy o tym użycie czasownika nûah, który ma m.in. znaczenie „osiąść”, „spocząć, „pozostać” (Rdz 8,4; Iz 25,10; Koh 7,9). Kilkakrotnie występuje on z rzeczownikiem $r \hat{u}^{a} h$. Wówczas duch uzdalniał tego, na kim spoczął, do wygłaszania proroctw (Lb 11,25-26) lub rozpoczęcia działalności prorockiej (2Krl 2,15). W Iz 11,2 spoczęcie ducha Bożego na mesjaszu zaowocuje udzieleniem szczególnych darów, które zostały przedstawione w trzech parach: mądrości i rozumu, rady i męstwa oraz wiedzy i bojaźni Bożej ${ }^{13}$. Każdy z nich zawiera w sobie tak wielkie bogactwo, że może stanowić przedmiot osobnego studium. Ich zestawienie razem ukazuje ideał człowieka w starotestamentowej myśli religijnej i etycznej ${ }^{14}$.

W Starym Testamencie mądrość (hoknmâ) jest ukazana jako towarzyszka Boga dokonującego dzieła stworzenia (Prz 8,22-31). Jest więc przed wszystkim, co zostało stworzone. Jest ona także udzielona ludziom, uzdalniając ich do poznania Boga, stworzonego świata, a także do nadprzyrodzonego działania. Dlatego mądrość

10 Przywołanie imienia ojca Dawida na początku wyroczni pełni dwie funkcje: 1) dynastia królewska rodzi się od nowa, wyrasta ze swoich nikłych i nieznanych początków (1Sm 16,1-13; 2Sm 7,18-20); 2) „odrośl” będzie nowym Dawidem. Izajasz podejmuje w ten sposób polemikę nie tylko ze współczesnymi sobie władcami (Achazem i Ezechiaszem), którym zarzucał słabość, m.in. w wymiarze politycznym, ale odnosi się krytycznie do Salomona. Ten król słynął przecież z wielkiej wiedzy i sprawiedliwości, a „mądrość Boża (hoknmat élōhîm) była w nim" (1Krl 3,28; por. 1Krl 3,5-14; 5,9-14; 10,1-3; 2Krn 1,7-12; 9,1-2; Syr 47,12-17). Jednak prawdziwie mądre i sprawiedliwe rządy nastaną dopiero wraz z przyjściem nowej „odrośli”.

11 Por. Marconcini, Księga Izajasza, 117: „Pąk rozwija się «za sprawą» Ducha”.

12 Por. Brzegowy, Ksiega Izajasza, I, 612.

13 Na temat różnicy między liczbą darów w tekście hebrajskim a greckim i łacińskim zob. Brzegowy, Księga Izajasza, I, 615.

14 Szczegółowe omówienie darów ducha Bożego zob. Kaiser, Isaiah 1-12, 255-257; Childs, Isaiah, 102-103; Beuken, Jesaja 1-12, 309; Paściak, Izajasz, 74-76; Stachowiak, Ksiega Izajasza, I, 257-259; Ma, Until the Spirit Comes, 38-41; Brzegowy, Ksiega Izajasza, I, 614-615. 
w sposób szczególny przysługiwała królowi lub temu, kto sprawował władzę nad narodem czy społecznością (Pwt 34,9). Uzdalniała bowiem do dobrego i twórczego działania (Wj 28,3), w tym także do sprawiedliwego rozstrzygania sporów i wydawania wyroków (1 Krl 3,12; Prz 8,15-16). Ponadto w Starym Testamencie mądrość ma wymiar religijny - wprowadza bowiem człowieka we właściwą relację z Bogiem. Wyrażają to słowa: „bojaźń Boża początkiem mądrości” (Ps 111,10; Prz 9,10; por. Hi 28,28; Prz 15,33; Iz 33,6). W takim wymiarze kieruje ona moralnym życiem ludzi, nawołując i uzdalniając do zachowywania Bożych przykazań. Według Iz 11,2 $r \hat{u}^{a} h$ h hokmâ uzdolni mesjasza przede wszystkim do funkcji sędziowskiej, jak na to wskazują dalsze wersety wyroczni (ww. 3-5). Dar rozumu (bînâ) jest pokrewny z hok uzupełnienie ${ }^{15}$. Akcent $\mathrm{w}$ tym przypadku jest położony bardziej na intelektualną zdolność człowieka. Rozum umożliwiał także podjęcie właściwej decyzji, a więc w działaniu był skierowany ku przyszłości. W bînâ kryje się także umiejętność rozróżniania dobra od zła, tego, co pożyteczne od tego, co szkodliwe, czy też prawdy od kłamstwa, oraz wybierania tego, co lepsze. To właśnie będzie uzdolnienie mesjasza.

W drugiej parze są wymienione rada i męstwo. Dar rady ('ẹṣ̂a) wyraża się w umiejętności podejmowania słusznych decyzji, a także w uzdolnieniu do najwłaściwszego rozwiązywania trudności, zwłaszcza w dziedzinie sądowniczej. Z kolei męstwo (gabûtrâ) jest kolejną cechą króla (1 Krl 15,23; $2 \mathrm{Krl}$ 10,34; $1 \mathrm{Krn}$ 29,29-30). Zapewniało ono pomoc w pokonywaniu wszelakich trudności i w ugruntowaniu panowania. Także i ono ma swoje źródło w Bogu (1 Krn 29,11-12; 2 Krn 20,6), ponieważ gəḅ̂urâ jest jednym z Jego przymiotów (Hi 12,13; 16,14; Ps 65,7; 89,14). W Iz 11,2 ēṣ̂a i gəb̆ ûrâ wzajemnie się uzupełniają - mesjasz będzie napełniony duchem rady, a więc uzdolniony do podejmowania najlepszych decyzji. Nie będzie on wydawał wyroków na podstawie tego, co widzi i słyszy, ani także - jako władca - nie będzie wysłuchiwał rad swoich książąt i doradców, jak mieli to zwyczaj, a nawet obowiązek, czynić królowie ziemscy (2Sm 16,15-23; $1 \mathrm{Krl} 12,6-11 ; 2 \mathrm{Krl} 6,8)$. Pouczenie spłynie na niego od samego Boga, dlatego te wyroki będą nieomylne. Potęga tych rad da mu także moc do ich realizowania - dzięki gəb̆ûrâ będzie mógł on wypełnić do końca podjęte plany i decyzje.

Ostatnia para to wiedza i bojaźń Boża. Wiedza (da'at $)$ jest równoznaczna z poznaniem, które zapewnia bliską relację ( $\operatorname{Rdz} 4,1 ; 1 \mathrm{Sm} 1,9)$, także w odniesieniu do Boga $(\mathrm{Oz} 2,22 ; 6,6)$. Dlatego prorocy bardzo często zarzucali ludowi wybranemu brak poznania Yhwh jako jeden z cięższych grzechów (Iz 1,3; Oz 4,1). W praktyce da'at oznaczała znajomość Bożego prawa. Bojaźń Boża (jira’at Yhwh) jest wyrazem głębokiej czci wobec Boga. Wynika ona z uznania Jego świętości. Uzdalnia także do właściwego poszanowania Stwórcy i oddawania Mu należnej chwały jako najwyż-

15 Zob. Pwt 4,6; 2Krn 2,11-12; Hi 28,12.20.28; 38,36; 39,17; Prz 1,2; 4,5.7; 7,4; 9,10; 16,16; 23,23; Iz 29,14; Dn 1,20 ; Syr 1,14 . 
szemu Panu. Bojaźń jest utożsamiana z mądrością. To właśnie w niej obdarowany mesjasz znajdzie szczególne upodobanie (w. 3). Zestawienie darów ducha Bożego w Iz 11,2 stanowi więc uroboros literacki - pierwszy człon jest ściśle związany z ostatnim, a ten odsyła do pierwszej pary darów ducha Bożego ${ }^{16}$. Tak zostaje wyrażona ich pełnia.

Pełnia darów, a właściwie przekazanie ducha mesjaszowi, zapowiada zarówno wielkość, jak i ciężar misji, którą będzie on musiał wykonać. Owo udzielenie ducha jest swoistym uzbrojeniem potomka Jessego do wielkich zadań, które go czekają. Opisują je - jeszcze w formie zapowiedzi - kolejne wersety (11,3b-5). Mesjasz będzie sprawował sądy w najwyższym stopniu sprawiedliwie. Na jego wyroki nie wpłyną ani własne odczucia, ani ludzkie podpowiedzi. Wykaże się on także wielką mocą wobec bezbożnych, którzy do tej pory pysznili się swoją siłą. Działanie dzięki duchowi Bożemu będzie odznaczało się sprawiedliwością (ședeq) i wiernością (ěmûnâ), a więc tymi cnotami, których brakowało ówczesnym władcom z dynastii Dawidowej. Sprawiedliwość i wierność wzajemnie się tutaj uzupełniają. Jedno bowiem odnosi się do postępowania wobec ludzi (ședeq), a drugie wyraża relację z Bogiem (ěmûnâ).

W ten sposób koniec pierwszej części Księgi Izajasza, w której występują wyrocznie mesjańskie, ukazuje zapowiadanego mesjasza jako władcę par excellence. Wcześniejsze zapowiedzi, wygłaszane w kontekście królewskim, dotyczyły m.in. jego narodzin, które miały się stać znakiem dla króla Achaza (Iz 7,10-14), oraz przyjścia na świat, co z kolei zapewniało światłość i radość (Iz 9,1-6, zwł. w. 5, w którym są wymienione imiona świadczące o jego władzy i potędze). W Iz 11 zapowiadany mesjasz jest ukazany jako ten, który sprawuje władzę królewską (wydawanie wyroków, ukaranie niesprawiedliwych). Dokonuje się to z woli i mocy samego Boga. Udzielony $r \hat{u}^{a} h \underline{h}$ Yhwh sprawia, że mesjasz otrzymuje udział w prerogatywach samego Boga. On też tworzy dynamiczną wieź pomiędzy Panem a „odroślą Dawidową). W kategoriach form obecności Boga, objawiających się dzięki Jego duchowi, o czym była mowa w pierwszym paragrafie, jest to kategoria przedstawiona w punkcie (1).

\section{Iz 42,1}

Wyrocznia Iz 42,1 należy do drugiej części księgi (rozdz. 40-55), a więc pochodzi z czasów przesiedlenia babilońskiego (VI w. przed Chr.). Stanowi ona początek pierwszej pieśni o Słudze Pańskim ('ébed $Y h w h$ ). Jest to tajemnicza postać, która przewija się w tych rozdziałach Księgi Izajasza (42,1-9; 49,1-9; 50,4-9; 52,13-53,12). Ustalenie tożsamości owego sługi i interpretacja tych poematów zajmuje egzegetów od bardzo dawna. Pomimo żmudnych badań i wielkiej liczby publikacji nie udało się

Na temat układu Iz 11,1-3 zob. Marlowe, „The Spirit Chiasm”, 44-57. 
jednak znaleźć ostatecznych rozwiązań. Wydaje się, że bardziej właściwe jest w tym przypadku skupienie się na działalności owego sługi, niż zakładanie i dopasowywanie orędzia biblijnego oraz wydarzeń historycznych w celu ustalenia jego pochodzenia, tożsamości i roli, jaką miał odegrać.

W początkowych słowach pierwszej pieśni o Słudze Pańskim sam Bóg mówi o jego wyborze i szczególnej więzi, jaką go obdarza. Wyraża się to w określeniach „sługa mój” ('ábdî) i „wybraniec mój” (bəhîirî). Bóg podtrzymuje go i znajduje w nim upodobanie, a powołuje go do ogłoszenia prawa, które jest określone także jako światło (Iz 42,6). Zgodnie z tą i kolejnymi pieśniami, znajomość woli Bożej ma ostatecznie doprowadzić pogan do zbawienia. To jest ostateczną misją Sługi Pańskiego. Deutero-Izajasz przypisuje mu przymioty właściwe Bogu, np. pełna sprawiedliwość, moc usprawiedliwienia $(53,11)$, dokonanie sądu (42,3-4). Ponadto realizacja zbawczego planu, obejmującego wszystkich ludzi, dokona się przez cierpienie, które Sługa Pański przyjmie dobrowolnie. Jego upokorzenie, męka i w końcu śmierć przyniosą narodom uzdrowienie ${ }^{17}$.

Tytuł 'ábdî - bo tak należy rozumieć to wyrażenie w Starym Testamencie - odnosi się m.in. do tak wielkich postaci, jak Abraham (Rdz 26,24), Mojżesz (Lb 12,7), Dawid $(2 \mathrm{Sm} 7,5)$, Hiob (Hi 1,8), Izajasz (Iz 20,3) ${ }^{18}$. Są to wielcy świadkowie wiary Starego Testamentu, którzy wykazywali się posłuszeństwem i wiernością względem Boga. Żyli oni w szczególnie bliskim związku ze swoim Panem. Każdy z nich również otrzymał od Niego wyjątkową misję i jednocześnie uzdolnienie do jej wypełnienia. W życie każdego z nich było wpisane także cierpienie. Sługa Pański z Księgi Izajasza jest jednym z nich. Wyrażenie 'a $\underline{b} d \hat{\imath}$ wyraża z jednej strony zależność i całkowite poddanie się Bogu, a z drugiej - podkreśla szczególną życzliwość i opiekę, jaką On roztacza nad swoim wybranym. Przejawia się to w stałym wsparciu, aby ów Sługa Boży mógł wypełnić swoje posłannictwo ${ }^{19}$. W Księdze Deutero-Izajasza rzeczownik 'ébed występuje 20 razy, z czego siedmiokrotnie odnosi się do Sługi Pańskiego ${ }^{20}$. Prorok używa go w podstawowym znaczeniu, podkreślając jego uległość względem Boga, ale zaznacza także więź, jaka zachodzi pomiędzy nimi.

Szczególną relację Boga z Jego Sługą opisuje osobliwe wyrażenie rāṣațâ nap̌rî̀ „dusza moja upodobała” w nim. Upodobanie wybrańca wypływa zatem z Bożego

17 Na temat problematyki pieśni o Słudze Pańskim zob.: Paściak, Izajasz, 83-145; Stachowiak, Księga Izajasza, II-III, 343-354; Watts, Isaiah 34-66, 650-658; Simian-Yofre, Sofferenza, 117-284; Pikor, „Izajaszowy Sługa”, 20-22; Brzegowy, Księga Izajasza, III, 525-547; Goldingay, „Servant of Yahweh”, 700-707.

18 Wyrażanie 'ábdî, jako sługa Boga, odnosi się także do Nabuchodonozora (Jr 43,10), Zorobabela (Ag 2,23), a więc przywódców narodów. Ponadto sługami Bożymi są nazwani prorocy (Jr 7,25; Am 3,7; Za 1,6) oraz kapłani i lewici (Jr 33,21). Tym tytułem są więc objęte trzy najważniejsze instytucje biblijnego Izraela: królowie, kapłani i prorocy. Także cały Izrael jest nazywany „mój sługa” (Iz 41,8-9; 42,19; Jr 46,28). W starożytnej literaturze Bliskiego Wschodu ten termin jest używany na określenie poddanych władcy lub czciciela bóstwa.

19 Por. Westermann, „ébe $\underline{b}$ - servant”, 826-831.

20 Zob. Iz 42,1; 49,3-5.6; 52,13; 53,11 oraz Iz 45,4-7; 50,10.11. 
wnętrza, a więc z najgłębszych Jego pokładów. Wynikać to może z faktu, że Sługa Pański wykazuje się bojaźnią Pańską. Ten dar, zgodnie z Iz 11,3a, znalazł szczególne upodobanie u niego. Natomiast w Ps 147,11 jest powiedziane: „Panu podobają się (rộseh) ci, którzy się Go boją?. Równie ważną rolę pełni tutaj czasownik tāmak („podtrzymywać”). Bóg podtrzymuje tych, którzy pełnią Jego wolę (Ps 16,4-5; 41,13; 63,9). W bezpośrednim kontekście analizowanej wyroczni Bóg zapewnia, że skoro podtrzymuje swojego wybrańca, to także go umacnia i wspomaga, co powinno odsunąć od niego wszelki lęk $(\mathrm{Iz} 41,10)^{21}$.

Równie bogate w treść jest wyrażenie bəhîrî̀. Oprócz Ps 89,4 występuje ono tylko w Księdze Deutero-Izajasza (zob. Iz 42,1; 43,20; 45,5). Przymiotnik bāhî̀r oznacza „wybrany”. W Starym Testamencie występuje on 13 razy i odnosi się do Mojżesza (Ps 106,23), Saula (2Sm 21,6), Dawida (Ps 89,4) czy kolektywnie do całego Izraela (Ps 105,43; 106,5; Iz 43,20; 65,22), przedstawionego eponimicznie przez któregoś z patriarchów (1Krn 16,13; Ps 105,6; Iz 45,4; 65,9). W tych ostatnich przykładach występuje paralelnie z rzeczownikiem 'ébed. Wybranie pozostaje czymś trwałym i nie zrywa ustalonych przez Boga więzów, nawet pomimo słabości człowieka, jak było to w przypadku całego Izraela, Saula czy także Dawida.

W Iz 42,1 Bóg powiedział, że daje Słudze swojego ducha. Poprzez czasownik nātattî jest wyrażony fakt, że ów duch jest własnością Yhwh, a samo udzielenie jest Jego darem. W Iz 42,1 - podobnie jak w Iz 11,2 przy użyciu czasownika nûah - podkreślona jest także trwałość tego daru. Duch Boży jest więc dany słudze-wybrańcowi w sposób stały, a nie przejściowy ${ }^{22}$. To podkreśla wielkość jego posłannictwa, jak również trudność powierzonej misji. Ponadto przez wyrażenie nātattî rûhĥ należy rozumieć, że został mu dany cały duch, a więc otrzymał on pełnię jego darów, o których szczegółowo była mowa w Iz 11,1-3. Świadczy to również o obecności Boga w życiu i posłannictwie swojego Sługi. Odwołując się do ustaleń przedstawionych w pierwszym paragrafie (Duch $\left(r \hat{u}^{a} h\right)$ jako forma obecności Boga w Starym Testamencie), jest to kategoria opisana w punkcie $(2)^{23}$.

Jednym z zadań Sługi Pańskiego będzie przyniesie narodom mišpaț. Użyty tutaj rzeczownik ma bardzo szerokie spektrum semantyczne: prawo, prawość, sprawiedliwość, decyzja, nakaz, sąd, proces sądowy, wyrok, sentencja, żądanie, nauczanie, obowiązek, ład, sposób postępowania, wzór ${ }^{24}$. Chociaż pochodzi on rdzenia špt (wyrażającego ideę sądzenia, rozstrzygania sporów, wydawania wyroków) nie może być ograniczony jedynie do kwestii związanych z prawem ${ }^{25}$. Wszystkie znaczenia mišpat

\footnotetext{
21 Por. Berges, Jesaja 40-48, 225; Paul, Isaiah 40-66, 184-185.

22 Por. Ma, Until the Spirit Comes, 92.

23 Może to być także kategoria przedstawiona w pierwszym paragrafie w punkcie (3), jeżeli przyjmie się interpretację Sługi Pańskiego jako naród (Izrael).

24 Por. BDB, 1048; HALOT II, 651-652.

25 Por. Liedke, „špt - to judge”, 3:1395-1397.„W polskiej literaturze biblijnej - jak odnotowuje Pikor zauważa się pewien konsensus w interpretacji misji Sługi sugerowanej przez termin mišpaț. Tłumaczony
} 
można sprowadzić do wspólnego mianownika, którym jest pewna obowiązująca reguła postępowania wynikająca z przepisów prawa, zachowania sprawiedliwości, uczciwości czy obyczajowości. Ten ład został ustanowiony i wprowadzony przez Boga w dziele stworzenia. Grzech jednak zniszczył owo mišpaț. Skutkiem tego był podział ludu Bożego ('am) na wiele narodów ( gôjìm). Sługa przyniesie zatem wszystkim ludziom ${ }^{26}$ porządek, co zostało podkreślone aż trzykrotnie w pierwszej pieśni (Iz 42,1.3.4). Jest to znaczące powtórzenie mišpaț, skoro w całej Księdze Deutero-Izajasza ten rzeczownik występuje $11 \mathrm{razy}^{27}$. Misja Sługi Yhwh będzie polegała na przywróceniu utraconej jedności ze Stwórcą i ukazaniu Go jako „jedynego i prawdziwego Boga, Stwórcę i Pana historii przez wykazanie nicości bóstw pogańskich i niedorzeczności ludzkich ambicji władzy”28. Tak objawia się „zbawcza sprawiedliwość Jahwe"29 obejmująca cały świat.

Zadaniem Sługi Pańskiego będzie więc doprowadzenie wszystkich narodów do czci jedynego Boga i postępowania według Jego woli. To jest to światło (hebr. 'ôr), o którym będzie mowa w dalszej części pieśni i kolejnej (Iz 42,6; 49,6). Na powodzenie tej misji duch Boży zostaje udzielony Słudze Pańskiemu. Umożliwia mu on zrozumienie, przyjęcie i wypełnienie do końca wyznaczonego zadania, które będzie polegało na byciu przymierzem dla ludzi. Realizując je, pozostanie on pełen pokory i cichości, ale zarazem mężny i wytrwały w działaniu. Treściowo jest to bliskie obrazowi opisanemu w Iz 11,3-5. Zdolność do realizacji zadania w takim wymiarze jest zapewniona przez ducha Bożego. On czyni Sługę Pańskiego całkowicie niezależnym od jakiegokolwiek człowieka i jego pomocy.

jest on jako „Prawo”, które Sługa ma głosić i rozpowszechniać w świecie”. Następnie zaznacza on, że „nowy impuls w poszukiwaniu zrozumienia celu misji Sługi przyszedł ze strony analizy semantycznej, która w odniesieniu do badanego terminu stała się standardowym etapem w egzegezie Iz 42,1-4 w początkach lat siedemdziesiątych ubiegłego wieku” (Pikor,„Izajaszowy Sługa”, 25-28). Jako przykłady twórczych badań w tym zakresie Pikor podaje prace Jeremiasa („mišpat”, 31-42), Beukena („mišpat”, 1-30) i Simian-Yofre (Sofferenza). Po syntetycznym przedstawieniu wyników egzegezy (zwłaszcza Beukena) sam wnosi znaczący wkład w badania rozumienia mišpaț w Iz 40-55. Jako jedną z konkluzji należy odnotować stwierdzenie: „Mišpaț, które ma zatriumfować, dotyczy praw samego Jahwe, dochodzącego swych racji wobec wymienionych podmiotów [tzn. obce narody, ich bóstwa, naród wybrany - uzupełnienie M.Sz.]".

26 Rzeczownik 'am oznacza w Iz 42,6 całą ludzkość (Rdz 11,6). Por. Janzen, „On the Moral Nature”, 472-473. Podobnie interpretują: Westermann, Isaiah 40-66, 100; Oswalt, The Book of Isaiah, 118; Stachowiak, Ksiega Izajasza, II-III, 103-104. Przeciwnie uważa Brzegowy, Księga Izajasza, III, 216-218.

27 Zob. Iz 40,14.27; 41,1; 42,1.3.4; 49,4; 50,8; 51,4; 53,8; 54,17.

28 Pikor, „Izajaszowy Sługa”, 28.

29 Sformułowanie zaczerpnięte za Tronina, „Władza”, 61-64. 


\section{Iz 61,1}

Kolejna wyrocznia ukazująca obecność i działanie Ducha Bożego w życiu wybranej postaci to Iz 61,1. Należy ona do trzeciej części księgi (rozdz. 56-66), która pochodzi z okresu po powrocie z przesiedlenia babilońskiego. Rozpoczyna ona dłuższą wypowiedź ukazującą zwiastuna dobrej nowiny (Iz 61,1-11).

Tutaj przemawia już sam obdarowany przez Boga, czyli mesjasz. Przedstawia on swoją misję, która - ze względu na użyte słownictwo - ściśle łączy się z powołaniem i zadaniami Sługi Pańskiego (Iz 42,1-7). Duch Boży jest nad nim, ponieważ Yhwh go namaścił. Namaszczenie było wprowadzeniem w urząd królewski $(1 \mathrm{Sm} \mathrm{16,13),} \mathrm{ka-}$ płański (Wj 28,41) i prorocki (1Krl 19,16). Czasownik māšah jest używany w Starym Testamencie zarówno $\mathrm{w}$ dosłownym, jak i figuratywnym znaczeniu ${ }^{30}$. Udzielenie ducha (lub napełnieniem nim) przy jednoczesnym namaszczeniu było wprowadzeniem w urząd królewski (1Sm 10,1.6-7; 16,13; 2Sm 23,1-5). Królewskość mesjasza objawia się w Iz 61,1-3 przede wszystkim w możliwości ogłaszania wolności skazańcom. Tutaj namaszczony sługa nie tylko zapowiada czy ogłasza powszechną amnestię, lecz jej udziela z własnej mocy. Pełni więc on większą rolę niż prorok czy herold. Więcej, wiele inicjatyw, które ma przeprowadzić ów mesjasz, w innych tekstach Starego Testamentu jest przypisywane wyłącznie Bogu. Na przykład w Iz 59,17 sam Pan przyobleka się w pomstę, aby jej dokonać. W Jego mocy leży także opatrywanie serc złamanych i leczenie chorób (Hi 5,18; Ps 147,3; Oz 6,1) oraz pomyślna odmiana losu Syjonu (Iz 60,17-22). Postać namaszczonego w Iz 61,1 dokonuje dzieła, które w nauczaniu Izajasza do tej pory było rozdzielone pomiędzy tak wielkie i ważne osoby, jak Cyrus, Sługa Pański, zwiastun dobrej nowiny czy sam prorok. Jakby tego było jeszcze mało, zaczyna on działać w duchu i z mocą, wykonując na ziemi to, co było objawieniem Bożej sprawiedliwości ${ }^{31}$. W ten sposób wyrażała się obecność Boga pośród swego ludu. Jest to kategoria opisana w punkcie (2) pierwszego paragrafu.

W Iz 61,1 duch Boży uzdalnia mesjasza także do działalności prorockiej, na co wskazuje wyrażenie šalāhanî („posłał mnie”). Podobna myśl została wyrażona w Iz 48,16 (por. także Iz 59,21). Jej owocem będzie głoszenie ubogim dobrej nowiny i czynienie dobrodziejstw (Iz 61,1-3a). Adresatami tego radosnego orędzia i wyzwolenia są “ănāwîm („ubodzy”). Prorocy Starego Testamentu nazywali w ten sposób tych, którzy przez bogatych rodaków, urzędników dworskich i sędziów byli celowo pozbawiani majątku, swoich praw i możliwości obrony (Am 2,7). Pomimo takiego traktowania pozostawali oni wierni Bogu i zachowywali Jego przykazania. Dlatego ‘̆nāwîm to pokorni, którzy całą ufność pokładali w Panu jako swoim obrońcy

30 Por. Blenkinsopp, Isaiah 56-66, 220.

31 Por. Brzegowy, Księga Izajasza, III, 732-733. Autor, po dokonaniu charakterystyki działalności namaszczonego przez Boga, stwierdza: „Żaden z proroków ST nie pojmował ani nie opisywał swojego urzędu tak szeroko, jak to zrobiono w tym tekście” (733). 
(So 2,3). Ich oczekiwanie zostało wynagrodzone przez Niego. Interwencję na rzecz ich dobra podejmie właśnie mesjasz (Iz 11,4). Jego misja przedstawiona w Iz 61,1-3 ma przemienić los ubogich, dając im upragnioną wolność i pocieszenie. Do wypełnienia tej trudnej misji uzdalniało udzielenie ducha i namaszczenie, które wiązało się z udzieleniem władzy do zaprowadzenia prawa i sprawiedliwości na ziemi. Ten motyw, to znaczy udzielenie ducha i wymierzenie sprawiedliwości, w całości przewijał się już w Iz 11,1-5 i 42,1-7.

Początek Iz 61,1 odpowiada Iz 42,1, a więc pierwszej pieśni Sługi Pańskiego ${ }^{32}$. W obu wyroczniach jest mowa o posłaniu z określoną misją tego, kto został obdarzony duchem Bożym. O wypełnieniu zadania jest też mowa w Iz 11,3-5. Wydaje się, że udzielenie ducha Bożego w sposób szczególny uzdalniało namaszczonego mesjasza do głoszenia dobrej nowiny. Jej treścią jest radykalna odmiana losu wszystkich pokrzywdzonych, a żyjących nienagannie. Można widzieć w tej wyroczni opis namaszczenia nie oliwą (jak zwykle to czyniono), lecz samym duchem Bożym. W ten sposób zostaje pośrednio wyrażona prawda, że Duch Święty mówił przez proroków.

Uznanie ciągłości pomiędzy Iz 42,1 a Iz 61,1 w kontekście udzielonego ducha Bożego zwraca uwagę na jeszcze jeden istotny fakt. Sługa Pański, powołany i umacniany przez Boga, ma ponieść śmierć za zbrodnie (hebr. peša) nie swoje, lecz „mojego ludu” (Iz 52,13-53,12, zwł. 53,8-9). Jest to „ofiara za grzechy” (hebr. 'āšām, Iz 53,10). Rzeczownik 'āšām oznacza winę, wykroczenie (Rdz 26,10; Jr 51,5), a także odszkodowanie (1Sm 6,3-17), ofiarę za grzechy (Kpł 19,21-22). W tym ostatnim przypadku przedmiotem złożonej ofiary mógł być baranek (Kpł 14,12-28; Lb 6,12), inne zwierzę (Kpł 5,6-7) lub nawet pieniądze (2Krl 12,17). Złożenie takiej ofiary - według Prawa Mojżesza - dawało odpuszczenie grzechów (Kpł 19,22). Dlatego ofiara typu āšām była określana jako bardzo święta (qōdeš qod̄āšìm hû', Kpł 7,1) 33. W Iz 53,10 należy przyjąć, uwzględniając wcześniejszą analizę mišpaț, znaczenie restytucji. Sytuacja naruszenia ustalonego przez Boga porządku wymagała reparacji, „to znaczy usunięcia skutków złych czynów" ${ }^{34}$. Grzech zniszczył przymierze Izraela z Bogiem, a jego odnowę przyniesie ofiara z życia Sługi. To naprawcze dzieło podejmuje on całkowicie i dobrowolnie. W przeciwieństwie do Izraela, który błądził i odwrócił się od swojego Pana, Sługa jest posłuszny wobec Jego woli i wypełnia ją do końca, a więc aż do oddania swojego życia. Tylko w ten sposób mogło być uleczone nieposłuszeństwo ludu wybranego ${ }^{35}$. Jest to wyjątkowa i jedyna w swoim rodzaju ofiara w Starym Testamencie.

32 Por. Ma, Until the Spirit Comes, 123-124. Wyrocznia Iz 61,1(-11) jest związana z pieśniami o Słudze Pańskim następującymi wątkami: 1) mowa w 1. os. 1. poj. (Iz 49,1-7; 50,4-9); 2) użycie wyrażenia 'ădōnāy Yhwh (Iz 50,4.5.9); 3) przyjście z pomocą utrudzonym i słabym (Iz 50,4); 4) rdzeń khh: knot o nikłym płomieniu (Iz 42,3), brak zniechęcenia (Iz 42,4), złamani na duchu (Iz 61,3); 5) czasownik šā $\underline{b} a r$ : nie złamie trzciny (Iz 42,3) i opatrzy złamane serca (Iz 61,1); 6) proklamacja amnestii (Iz 42,7 i 61,1).

33 Por. Tronina, „Rozgrzeszenie”, 19-28; tenże, Księa Kapłańska, 114-117.

34 Pikor, „Izajaszowy Sługa”, 36-37.

35 Por. Witczyk, Pascha, 149-175; Pikor, „Izajaszowy Sługa”, 35-39. 
Wyjątkowość misji Sługi Pańskiego nie kończy się jednak z chwilą złożenia go do grobu (Iz 53,9). Nieoczekiwanie pada zapowiedź, że on „ujrzy potomstwo, dni przedłuży... ujrzy światło, nasyci się wiedzą swoją" (Iz 53,10-11), a ponadto Bóg zapewnia: „przydzielę mu wielkich i potężnych dam mu jako łup” (Iz 53,12). W czwartej pieśni jest więc mowa nie tylko o powrocie do życia owego Sługi, ale także o nagrodzie dla niego ${ }^{36}$. Stało się to możliwe dzięki duchowi Bożemu, który ma moc ożywiania nawet umarłych i pogrzebanych. W Iz 61,1 przemawia zatem i przystępuje do realizacji swojej misji Sługa redivivus - mesjasz przywrócony do życia i namaszczony. Udzielenie ducha wypływa oczywiście z upodobania Bożego. Jednak sam mesjasz także odznacza się szczególnym przymiotami, które usposabiają go do podjęcia misji wyznaczonej mu przez Boga. Przede wszystkim upodobał on sobie dar bojaźni Bożej, która czyni jego życie mądrym (Iz 11,1-3a) i zbliża Go do Boga. To jest jego odpowiedź na obdarowanie duchem Bożym. Ponadto zgadza się on oddać swoje życie. W Iz 53,10 jest powiedziane o Słudze Pańskim: 'im-tāsî̀m 'āšām napšô „jeżeli jego życie stanie się ofiarą”. Sługa oddaje zatem swojego ducha - życie (nepeš). Tekst hebrajski mówi dokładnie o wylaniu na śmierć swojego ducha po cierpieniach (Iz 53,11a: mēǎmal nap̌sô..., Iz 53,12b: heěrrāh lammāwet nap̌šo ${ }^{37}$. Sługa Pański oddaje więc wszystko, co ma, patrząc z ziemskiego punktu widzenia. Za to „wszystko” otrzymuje on od Boga jeszcze więcej, to znaczy ducha Bożego $\left(r \hat{u}^{a} h \mathrm{Y} Y h w h\right)^{38}$.

\section{Relacje zachodzące pomiędzy Iz 11,1-2 a Iz 42,1 i lz 61,1}

Analizowane wyrocznie są wypowiedziami różnych osób. Zestawione razem stanowią kolejne odsłony postaci mesjasza. Najpierw przemawia prorok, który zapowiada niezwykłą postać (mesjasza) obdarowanego wyjątkowym darem (duchem Bożym). Następnie zabiera głos Bóg, ogłaszając wypełnienie tego, co zostało wcześniej zapowiedziane, i przedstawiając misję mesjasza. Siłę do jej wypełnienia będzie miał dzięki udzielonemu duchowi. Ostatecznie przemawia ten, który narodził się i wyrósł jako nowa różdżka z pnia Jessego (Iz 11,1; por. także Iz 7,14 i 9,5-6 - pierwsza część Księgi Izajasza), a następnie został powołany przez Boga i obdarzony zaszczytnym tytułem „Mój Sługa” (Iz 42,1 - druga część Księgi Izajasza). W trzeciej części tej księgi został on już namaszczony. Należy w tym widzieć przekazanie mu władzy, którą miał sam Bóg. Mesjasz miał także stać się przymierzem dla narodów. Pamiętać należy, że Stary Testament zawsze podkreśla obecność Boga przy zawieraniu przymierza.

36 Por. Pikor, „Ze śmierci do życia”, 310-332; Lemański, „Sługa JHWH”, 54-59; Brzegowy, „Męka i śmierć”, 49-53.

37 Por. Childs, Isaiah, 417-420.

38 W Iz 32,15 jest mowa o wylaniu z wysokości ducha Bożego przy użyciu czasownika ‘ārāh, co sprawi rozkwit świata przyrody. 
W tym przypadku mesjasz staje w Jego imieniu. Jest to możliwe dzięki udzieleniu mu przez Boga duchowi, który - jak zaznaczono na początku artykułu - jest jedną $\mathrm{z}$ form obecności Yhwh. Relacje ukazuje poniższa tabela.

\begin{tabular}{|c|c|c|c|c|c|}
\hline Wyrocznia & Mówca & $\begin{array}{l}\text { Czasownik } \\
\text { z przyimkiem }\end{array}$ & $\begin{array}{l}\text { Stan } \\
\text { udzielenia ducha }\end{array}$ & $\begin{array}{l}\text { Odbiorcy } \\
\text { misji }\end{array}$ & $\begin{array}{l}\text { Owoc } \\
\text { misji }\end{array}$ \\
\hline Iz $11,1-3 a$ & Prorok & $n \hat{u}^{a} h$ ' & $\begin{array}{l}\text { zapowiedź } \\
\text { (opis misji) }\end{array}$ & $\begin{array}{l}\text { biedni } \\
\text { pokorni } \\
\text { pyszni } \\
\text { natura }\end{array}$ & $\begin{array}{l}\text { sprawiedliwość } \\
\text { pokój }\end{array}$ \\
\hline Iz 42,1 & Bóg & nātan 'ālāw & $\begin{array}{l}\text { wypełnienie } \\
\text { (posłanie) }\end{array}$ & narody & $\begin{array}{l}\text { mišpaț } \\
\text { znajomość Boga } \\
\text { przymierze }\end{array}$ \\
\hline Iz 63,1 & Mesjasz & ${ }_{-39}^{39}$ ‘alāj & $\begin{array}{l}\text { potwierdzenie } \\
\text { (realizacja) }\end{array}$ & $\begin{array}{l}\text { ubodzy } \\
\text { uwięzieni }\end{array}$ & wolność \\
\hline
\end{tabular}

Ponadto pomiędzy omówionymi wyroczniami zachodzą relacje, które rozwijają główną ideę, czyli udzielenie ducha Bożego wybranej postaci - mesjaszowi. Wyraża się to w ciągłości, zgodności i progresie objawienia tej prawdy.

5.1. Bóg jest dawcą ducha - udziela go jako swojego daru.

5.2. Bóg udziela ducha według swojego upodobania.

5.3. Udzielenie ducha jest czymś trwałym, o czym świadczą wyrażenia nûah 'al i nātan 'al.

5.4. Udzielenie ducha, jako Bożego daru, poprzedza powołanie obdarowanego do wypełnienia konkretnej misji.

5.5. Duch obdarza dobrami, które uzdalniają do wypełnienia misji wyznaczonej przez Boga.

5.6. Obdarowany przez ducha pozostaje w ścisłym związku z Bogiem, co wyraża m.in. zwrot „mój wybrany”.

5.7. Obdarowany jest całkowicie posłuszny Bogu, co wyraża m.in. zwrot „mój sługa”.

5.8. Mesjasz ma pochodzenie królewskie według ziemskiego rodowodu („różdżka z pnia Jessego").

5.9. Królewskość mesjasza zostaje potwierdzona i poszerzona przez Boga poprzez przekazanie mu swojej władzy w sprawowaniu sądów, obdarzeniu wolnością i leczeniu ludzkich słabości.

39 We wszystkich wyroczniach występuje przyimek 'al. Brakujący czasownik w Iz 61,1 można uzupełnić przez np. nûah (rûah 'ădōnāy yhwh nāhâ âlāy - „duch Pana Yhwh spoczął na mnie”). Syntagma rûah z przyimkiem 'al występuje jeszcze w Lb 11,17.26; $2 \mathrm{Krl} 2$ 2,9.15; Iz 32,15; 44,3; 59,21; Ez 11,5). Por. Goldingay - Payne, Isaiah 40-55, 214. 
5.10. Mesjasz będzie wykonywał swoją misję w pokorze i z wielką cierpliwością.

5.11. Obdarowany mesjasz jest posłany do biednych i pokornych, pokrzywdzonych i uwięzionych.

5.12. Owocem działania mesjasza będzie obdarowanie radością wszystkich smutnych i pokrzywdzonych.

5.13. W przywołanych wyroczniach duch Boży uzdalnia mesjasza do zaprowadzenia prawa i sprawiedliwości, które obejmą przede wszystkim ubogich i pokrzywdzonych.

5.14. Mesjasz wyposażony w ducha Bożego będzie miał siłę, aby pokonać i ukarać pysznych i bezbożnych.

5.15. Działalność mesjasza przekroczy granice Izraela i zostanie skierowana ku wszystkim mieszkańcom ziemi.

5.16. Ostatecznym owocem jego działalności będzie zaniesienie narodom światła (tzn. objawienie prawdy o Bogu) i ustanowienie przymierza (tzn. zapewnienie relacji pogan $\mathrm{z}$ Bogiem).

\section{Odniesienia w Nowym Testamencie}

Wszystkie analizowane wyrocznie znalazły się w Nowym Testamencie w formie cytatu bądź nawiązania. Zacytowane są dwie z nich: Iz 42,1-3 w Mt 12,18-20 oraz Iz 61,1-2 w Łk 4,18-1940. Oczywiście odnoszą się do Jezusa Chrystusa i są przywołane, aby potwierdzić Jego mesjańskie posłannictwo.

Tekst Iz 42,1 jest użyty przez św. Mateusza w opisie galilejskiej działalności Pana Jezusa pomiędzy drugą a trzecią mową (Mt 11,1-12,50). Na uwagę zasługuje fakt, że jest to najdłuższy cytat Starego Testamentu w jego Ewangelii. Ten ewangelista często przywołuje wypowiedzi Izajasza, ukazując go jako mesjańskiego proroka, który zapowiedział narodziny Mesjasza (Iz 7,14 w Mt 1,23), wystąpienie św. Jana Chrzciciela (Iz 40,3 w Mt 3,3), głoszenie Dobrej Nowiny jako światłości (Iz 9,1-2 w Mt 4,15-16) czy wzięcie przez Jezusa ludzkich słabości (Iz 53,4 w Mt 8,17) ${ }^{41}$. Przywołując Iz 42,1-3, św. Mateusz ukazuje, że Chrystus z całą łagodnością przyniesie narodom zbawienie. Ma ono wymiar już doczesny, bo On, jako Sługa Pański, przynosi pełne uzdrowienie i uwolnienie $\mathrm{z}$ wszelkiej słabości, jak pokazuje to kontekst bezpośredni, czyli uzdrowienie człowieka z uschłą ręką (Mt 12,9-14). Objawienie Pana Jezusa jako umiłowanego Syna, w którym Bóg Ojciec ma upodobanie, nastąpiło podczas chrztu (Mt 3,17) i zostało potwierdzone w scenie Przemienienia (Mt 17,5).

\footnotetext{
40 Zob. także 1) Iz 11,1: Mt 2,23; Ap 5,5; 22,16; 2) Iz 42,1: Mt 3,17; Mk 1,11; Łk 9,35; 3) Iz 61,1: Mt 11,5; Łk 7,22; Dz 4,27; 10,38.

41 Por. Moyise, The Old Testament, 39.
} 
Wtedy także (tzn. podczas chrztu) nastąpiło zapowiadane przez Izajasza udzielenie Ducha Świętego (Mt 3,16). Jego mocą Jezus wypełni swoją mesjańską misję do końca. Święty Mateusz podkreśla, że Pan Jezus „doprowadzi do zwycięstwa sąd”. Użyty tutaj grecki rzeczownik krisis odpowiada hebrajskiemu miṣpăt. Tak właśnie jest najczęściej tłumaczony w LXX, np. w omawianych wyroczniach (Iz 11,4; 42,1.3-4). W Mt 12,20 krisis oznacza sąd rozumiany jako dzieło miłości objawiające Boga - sprawiedliwego Sędziego, który dokonuje je przez swojego Sługę - Chrystusa ${ }^{42}$.

W Łk 4,18-19 jest cytowany Iz 61,1-2 wraz z 58,6. Ewangelista przywołuje ten tekst jako fragment odczytany przez Pana Jezusa w synagodze w Nazarecie. W ten sposób zapoczątkował On swoją publiczną działalność, wskazując, że przyszedł, aby ogłosić Dobrą Nowinę ubogim, uwolnić więźniów i uzdrowić chorych, a przede wszystkim ogłosić „,rok łaski Pana”. To jest Jego misja, ponieważ On jest Tym, o którym mówił prorok. Świadczy o tym stwierdzenie: „Dziś spełniły się te słowa Pisma, które słyszeliście". Pan Jezus przedstawia się więc jako namaszczony przez Boga i posłany przez Niego, a przede wszystkim obdarzony duchem Bożym. Przewyższa On jednak posługę Sługi Pańskiego z Księgi Izajasza, ponieważ przynosi wyzwolenie nie tylko w wymiarze ziemskim, ale także duchowym i eschatologicznym. Święty Łukasz wyrazi to z całą mocą w Dz 10,38, gdzie nawiązując ponownie do Iz 61,1, mówi o Jezusie Chrystusie: „Bóg namaścił Go Duchem Świętym i mocą. Przeszedł On dobrze czyniąc i uzdrawiając wszystkich, którzy byli opętani przez diabła, ponieważ Bóg był z Nim”. Zstąpienie Ducha Świętego na Pana Jezusa w czasie chrztu (Łk 3,21-22) jest jednocześnie namaszczeniem, z którym łączy się określona misja i udzielenie mocy. Owo „Bóg był z Nim” jest zapewnione przez Ducha Świętego ${ }^{43}$. W tym przypadku nie jest to jednak jedynie forma obecności, jak miało to miejsce w Starym Testamencie, lecz pełne i rzeczywiste istnienie.

\section{Bibliografia}

Alberts, R. - Westermann, C., „rü $\hat{u}^{a}$ - spirit”, Theological Lexicon of the Old Testament (red. E. Jenni - C. Westermann; trans. M.E. Biddle) (Peabody, MA: Hendrickson 1997) III, 1202-1220.

Beaton, R., „Messiah and Justice. A Key to Matthew's Use of Isaiah 42,1-4”, Journal for the Study of the New Testament 75 (1999) 5-23.

Berges, U., Jesaja 40-48 (Herders Theologischer Kommentar zum Alten Testament; Freiburg: Herder 2008).

\footnotetext{
42 Por. Homerski, Ewangelia, 206-207; Beaton, „Messiah”, 17-21.

43 Por. Green, The Gospel, 209-213; Kudasiewicz, „Mesjańska działalność”, 223-224; Mielcarek, „Jezusowe głoszenie”, 126-131; Mickiewicz, „Namaszczenie”, 86-88; tenże, Ewangelia, 260-262.
} 


\section{MARIUSZ SZMAJDZIŃSKI}

Beuken, W.A.M., Jesaja 1-12 (Herders Theologischer Kommentar zum Alten Testament; Freiburg: Herder 2003).

Beuken, W.A.M., „mišpat: The First Servant Song and its Context”, Vetus Testamentum 22/1 (1972) 1-30.

Blenkinsopp, J., Isaiah 56-66. A New Translation with Introduction and Commentary (The Anchor Bible 19; New York: Doubleday 2003).

Brown F., The Brown-Driver-Briggs Hebrew and English Lexicon with an Appendix Containing the Biblical Aramaic (Peabody: Hendrickson 1999) (= BDB).

Brzegowy, T., Księga Izajasza. I. Rozdziały 1-12.Wstęp - przekład z oryginału - komentarz (Nowy Komentarz Biblijny 22/1; Częstochowa: Edycja Świętego Pawła 2010).

Brzegowy, T., Księga Izajasza. III. Rozdziały 40-66. Wstęp - przekład z oryginału - komentarz (Nowy Komentarz Biblijny 22/3; Częstochowa 2019).

Brzegowy, T., „Męka i śmierć Mesjasza według pieśni Izajasza o Słudze Jahwe”, Krzyż Twój wielbimy (red. A. Paciorek - A. Tronina - P. Łabuda) (Scripturae Lumen 3; Tarnów: Biblos 2011) 31-67.

Childs, B.S., Isaiah (The Old Testament Library; Louisville, KY: Westminster 2001).

Goldingay, J., „Servant of Yahweh”, Dictionary of the Old Testament Prophets (ed. M.J. Boda J.G. Mc Conville) (Downers Grove, IL - Nottingham: IVP Academic 2012) 700-707.

Goldingay, J. - Payne, D., A Critical and Exegetical Commentary on Isaiah 40-55 (London New York: Clark 2007).

Green, J., The Gospel of Luke (The New International Commentary on the New Testament; Grand Rapids, MI - Cambridge UK: Eerdmans 1997).

Homerski, J., Ewangelia według św. Mateusza. Wstęp - przekład z oryginału - komentarz (Pismo Święte Nowego Testamentu 3/1; Poznań - Warszawa: Pallottinum 1979).

Janzen, J.G., „On the Moral Nature of God's Power: Yahweh and Sea on Job and Deutero-Isaiah”, The Catholic Biblical Quarterly 56/3 (1994) 458-478.

Jeremias J., „mišpaṭ im ersten Gottesknechtslied (Jes. XLII 1-4)”, Vetus Testamentum 22/1 (1972) 31-42.

Kaiser, O., Isaiah 1-12. A Commentary (trans. J. Bowden) (The Old Testament; London: SCM 1991).

Koehler, L. - Baumgartner, W. - Stamm, J.J., The Hebrew and Aramaic Lexicon on the Old Testament (tł. T. Richardson) (Leiden: Brill 1994-2000) I-V (= HALOT).

Krawczyk, R., Nadzieje mesjańskie w historii starożytnego Izraela (Warszawa: Wydawnictwo Sióstr Loretanek 2008).

Kudasiewicz, J., „Mesjańska działalność Jezusa jubileuszowym rokiem łaski (Łk 4,16-30)”, Słowo Twoje jest prawdą. Księga pamiątkowa dla Księdza Profesora Stanisława Mędali CM w 65. rocznice urodzin (red. W. Chrostowski) (Ad Multos Annos; Warszawa: Vocatio 2000) 212-224.

Lemański, J., „Sługa JHWH (Iz 53,10-11a) i problem zmartwychwstania”, Verbum Vitae 15 (2009) 35-59.

Liedke, G., „špt - to judge”, Theological Lexicon of the Old Testament (red. E. Jenni - C. Westermann; tł. M.E. Biddle) (Peabody, MA: Hendrickson 1997) III, 1392-1399.

Ma, W., Until the Spirit Comes. The Spirit of God in the Book of Isaiah (Journal for the Study of the Old Testament. Supplement Series 271; Sheffield: Sheffield Academic Press 1999). 
Marconcini, B., Księga Izajasza (tł. J. Dembska) (Rozumieć Stary Testament. Komentarze duchowe; Kraków: Wydawnictwo M 2000).

Marlowe, W.C., „The Spirit Chiasm in Isaiah 11,2a-3a”, Scandinavian Journal of the Old Testament 28/1 (2014) 44-57.

Mickiewicz, F., Ewangelia według św. Łukasza (rozdziały 1-11). Wstęp - przekład z oryginału - komentarz (Nowy Komentarz Biblijny 3/1; Częstochowa: Edycja Świętego Pawła 2011).

Mickiewicz, F., „Namaszczenie Jezusa Duchem Świętym na proroka według Łk 3,21-22; 4,18; Dz 10,38", Collectanea Theologica 77/1 (2007) 69-88.

Mielcarek, K., Jezus - Ewangelizator ubogich (Łk 4,16-30). Studium z teologii św. Łukasza (Warszawa: And 1994).

Mielcarek, K., „Jezusowe głoszenie słowa według trzeciego ewangelisty (Łk 4,18n)”, Verbum Vitae 7 (2005) 119-138.

Moyise, S., The Old Testament in the New. An Introduction (The Continuum Biblical Studies Series; London - New York: Continuum 2001).

Oswalt J.N., The Book of Isaiah. Chapters 40-66 (The New International Commentary on the Old Testament) (Grand Rapids, MI - Cambridge: Eerdmans 1998).

Paściak, J., Izajasz wieszczem Chrystusa (Attende Lectioni 12; Katowice: Księgarnia św. Jacka 1987).

Paul, Sh. M., Isaiah 40-66. Translation and Commentary (Grand Rapids, MI: Eerdmans 2012).

Pikor, W., „Izajaszowy Sługa Jahwe a nowe przymierze. Analiza kontekstualna Iz 42,1-9”, Zeszyty Naukowe Katolickiego Uniwersytetu Lubelskiego 49/2 (2006) 19-42.

Pikor, W., „Ze śmierci do życia. Teologiczne przesłanie Czwartej Pieśni o Słudze Jahwe (Iz 52,13-53,12) w świetle jej struktury”, „Bóg jest miłościa” (1J 4,16). Studia dla Księdza Profesora Józefa Kudasiewicza w 80. rocznice urodzin (red. W. Chrostowski) (Rozprawy i Studia Biblijne 25; Warszawa: Vocatio 2006) 310-332.

Simian-Yofre, H., Sofferenza dell' uomo e silenzio di Dio nell' Antico Testamento e nella letteratura del Vicino Oriente Antico (Studia Biblica 2; Roma: Città Nuova 2005).

Stachowiak, L.R., Księga Izajasza. I. Wstęp - przekład z oryginału - komentarz (Pismo Święte Starego Testamentu 9/1; Poznań: Pallottinum 1996).

Stachowiak, L.R., Księga Izajasza. II-III. Wstęp - przekład z oryginału - komentarz (Pismo Święte Starego Testamentu 9/2; Poznań: Pallottinum 1996).

Synowiec, J.S., Oto twój król. Mesjasz w pismach Starego Przymierza (Kraków: Wyższe Seminarium Duchowne oo. Franciszkanów 1992).

Tronina, A., Księga Kapłańska. Wstęp - przekład z oryginału - komentarz (Nowy Komentarz Biblijny 3; Częstochowa: Edycja Świętego Pawła 2006).

Tronina, A., „Rozgrzeszenie według kapłańskiej «tory ofiar» (Kpł 5,1-6)”, Roczniki Teologiczne 51/1 (2004) 19-28.

Tronina, A., „Władza Boga nad światem a ład moralny według Księgi Hioba”, Verbum Vitae 14 (2008) 57-70.

Watts, J.D.W., Isaiah 34-66 (Word Biblical Commentary 25; Nashville, TN: Nelson 2005).

Westermann, C., „ébed - servant”, Theological Lexicon of the Old Testament (red. E. Jenni C. Westermann; tł. M.E. Biddle) (Peabody, MA: Hendrickson 1997) II, 819-831.

Westermann, C., Isaiah 40-66 (tł. D.M.G. Stalker) (The Old Testament Library; London: SCM 1990). 
Witczyk, H., Pascha Jezusa odpowiedzią Boga na grzech świata. Eschatologiczna ofiara ekspiacji i nowego Przymierza (Lublin: Wydawnictwo KUL 2003).

Witczyk, H., „Pokorny wołał, i Pan go wystuchał” (Ps 34,7a). Model komunikacji diafanicznej w Psalmach (Lublin: RW KUL 1997). 